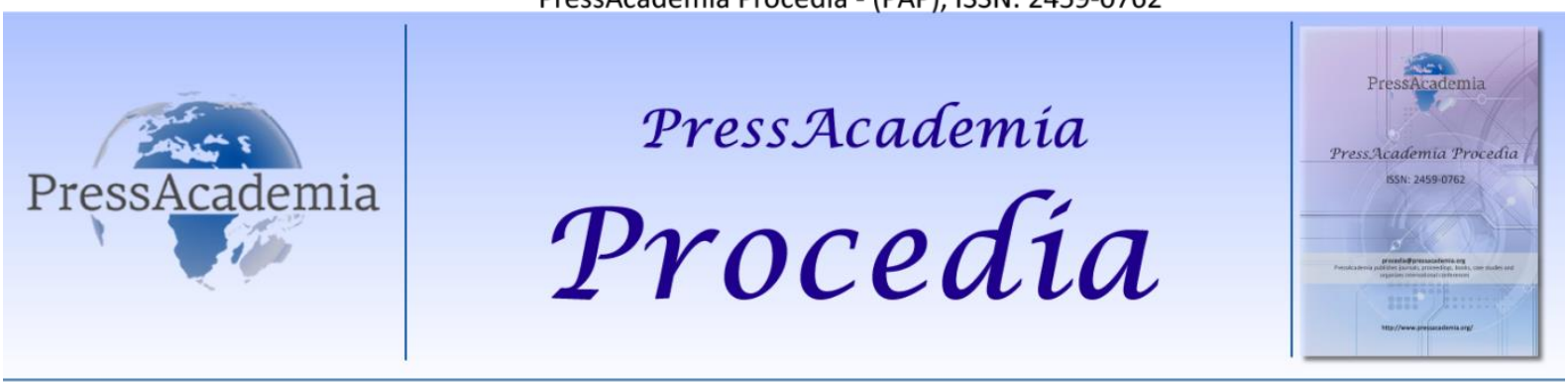

2nd World Conference on Technology, Innovation and Entrepreneurship

May 12-14, 2017, Istanbul, Turkey. Edited by Sefer Şener

\title{
OPTIMIZATION OF DISSOLUTION OF COLEMANITE ORE IN POTASSIUM DIHYDROGEN PHOSPHATE SOLUTION (KH2PO4)
}

\author{
DOI: 10.17261/Pressacademia.2017.617 \\ PAP-WCTIE-V.5-2017(55)-p.402-409
}

\section{Ozlem Karagoz, Soner Kuslu}

Atatürk University, Engineering Faculty, Department of Chemical Engineering, 25240 Erzurum, Turkey.

\begin{abstract}
Boron is one of the most important richnesses of Turkey which has approximately $72 \%$ of the known boron reserves globally. The production of boron compounds has essentially expanded recently due to increasing demands. Colemanite rich in boron is a common raw material to produce boron components and the first step of this process is the dissolution of colemanite by using different leaching solutions. The main aim of the study is to investigate the optimization of dissolution of colemanite in potassium dihydrogen phosphate $\left(\mathrm{KH}_{2} \mathrm{PO}_{4}\right)$ solution. Taguchi method was used to determine the optimum conditions while effectiveness of the parameters were identified by variance analysis. Reaction temperature (T), $\mathrm{KH}_{2} \mathrm{PO}_{4}$ concentration (C), stirring speed (W), solid to liquid ratio (S/L), and particle size (D) of colemanite were selected as parameters affecting the rate of colemanite dissolution. The optimum conditions for these parameters were determined. As a result of the experiment made under optimum conditions, both $98 \%$ of $\mathrm{B}_{2} \mathrm{O}_{3}$ passed into the solution and potassium borate by-product were produced by crystallization.
\end{abstract}

Keywords: Colemanite, optimization, potassium dihydrogen phosphate, taguchi method.

\section{INTRODUCTION}

Boron is an important element which has the capacity to form a large number of complex chemical compounds. Boron is videly used in a diversity of applications including the nuclear, fuel, glass, electronic and computer, energy devices, medicine, cosmetics, paper, plastics, metallurgy, textile and agriculture industries [1]. Almost $72 \%$ of the world boron reserves are found in Turkey. The most important of these boron ores are colemanite, tincal and ulexite. Colemanite has a monoclinic crystal structure with a chemical formula of $2 \mathrm{CaO} .3 \mathrm{~B}_{2} \mathrm{O} 3.5 \mathrm{H}_{2} \mathrm{O}$. It is used to produce boric acid $\left(\mathrm{H}_{3} \mathrm{BO}_{3}\right)$, which is an important boron chemical and based on the reaction of colemanite and sulfuric acid $\left(\mathrm{H}_{2} \mathrm{SO}_{4}\right)$ at $88-92{ }^{\circ} \mathrm{C}$ [2]. The use of $\mathrm{H}_{2} \mathrm{SO}_{4}$ in boric acid production from colemanite ore has several problems cuse of decomposition of some minerals like calcium and magnesium in the colemanite ore by $\mathrm{H}_{2} \mathrm{SO}_{4}$. On the other hand, a form of gypsum that is a by-product of this process is released into the nature and causes environmental pollution [3, 4].

It was known that there are many studies in the literature about the investigation of the optimum condition for boric acid extraction from various minerals with using different leaching solutions. Some of them are showed in Table 1.

The aim of our study is to investigate the optimum condition for boric acid extraction from colemanite ore with using $\mathrm{KH}_{2} \mathrm{PO}_{4}$ solution in a mechanical stirrer system and declare an alternative process to produce the boric acid. The gypsum is not regarded as a by-product during the process. This prevents both environmental pollution and facilitates filtration. This is the most important advantage of our process when compared to other boric acid production processes. In addition, because it is a weak acid, $\mathrm{KH}_{2} \mathrm{PO}_{4}$ does not cause the dissolution of other minerals except boron. Thus, the boric acid purity is increased. For these reasons we believe that the investigation of the dissolution kinetics of colemanite in $\mathrm{KH}_{2} \mathrm{PO}_{4}$ solutions will be beneficial to the solution of these problems appeared during boric acid production. No study was found including the dissolution kinetics of colemanite in $\mathrm{KH}_{2} \mathrm{PO}_{4}$ solutions. Reaction temperature, $\mathrm{KH}_{2} \mathrm{PO}_{4}$ concentration, stirring speed, solid to liquid ratio, and particle size of colemanite were selected as parameters. Taguchi method was used to determine the optimum conditions for boric acid extraction from colemanite. 
Table 1: Earlier Studies on the Reactions of Various Minerals with Using Different Teaching Solutions

\begin{tabular}{lcc}
\hline Boron Minerals & Leaching Solutions & References \\
\hline \multirow{3}{*}{ Colemanite } & Supercritical carbon dioxide & {$[5]$} \\
& Propionic acid & {$[6]$} \\
& Nitric Acid & {$[7]$} \\
& Carbon Dioxide & {$[4]$} \\
Tincal & Phosphoric Acid & {$[8]$} \\
& Sulphur dioxide & {$[9]$} \\
& Water & {$[10]$} \\
Ulexite & Sulphuric acid & {$[11]$} \\
& Phosphate acid & {$[12]$} \\
\hline
\end{tabular}

\section{MATERIALS AND METHOD}

\subsection{Materials}

The colemanite ore used in the study was obtained from Emet-Mine (Kütahya-Türkiye). The samples was crushed, ground, and then sieved by using ASTM standard sieves to obtain 1550, 780, 390, $165 \mu \mathrm{m}$ average size fractions. The chemical composition of the ore was determined by volumetric and gravimetric methods. The chemical analysis of these fractions is given in Table 2. There was no definitive trend between the $\mathrm{B}_{2} \mathrm{O}_{3}$ content and particle size ranges. XRD was obtained from the original sample and is shown in Fig. 1. Investigation of the diffractogram indicates that in the sample from Emet, apart from clay, the basic components are colemanite $\left(2 \mathrm{CaO} \cdot 3 \mathrm{~B}_{2} \mathrm{O}_{3} \cdot 5 \mathrm{H}_{2} \mathrm{O}\right)$ and Calcium oxide $(\mathrm{CaO})$.

Table 2: Chemical Analysis of Colemanite Minerals

\begin{tabular}{lllll}
\hline Component & $\mathrm{B}_{2} \mathrm{O}_{3}$ & $\mathrm{CaO}$ & $\mathrm{H}_{2} \mathrm{O}$ & $\mathrm{SiO}_{2}$ and others \\
\hline$\%$ & 44.20 & 26.75 & 22.20 & 6.40 \\
\hline
\end{tabular}

Fig. 1: X-ray Diffraction of Colemanite Ore

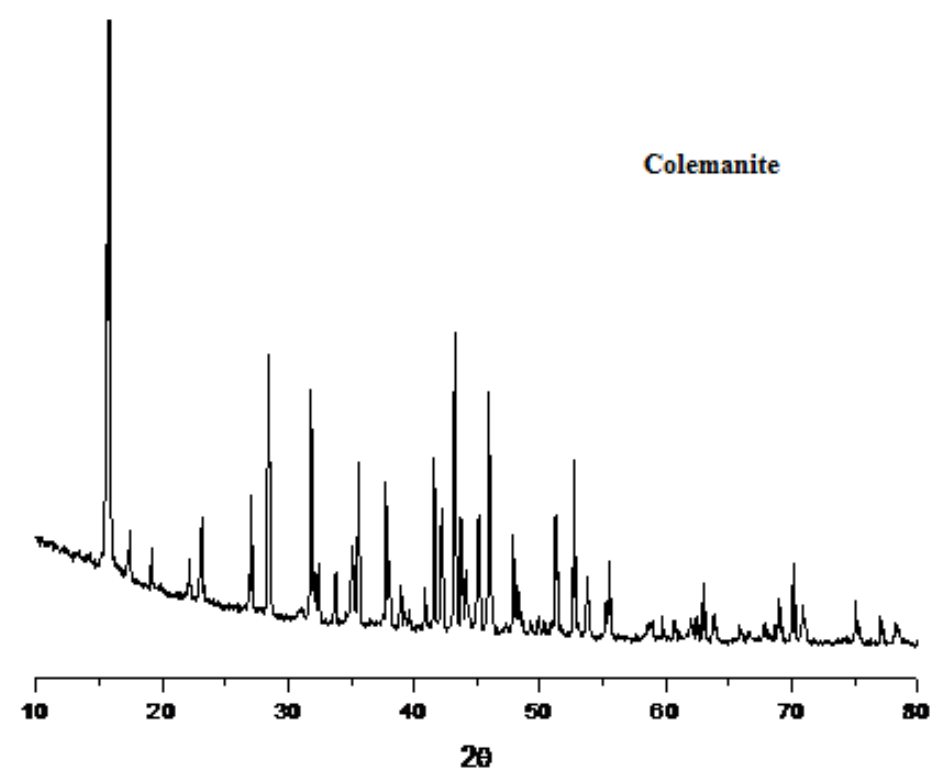




\subsection{Experimental Procedure}

A $500 \mathrm{~mL}$ jacketed glass reactor furnished with reflux condenser, a mechanical stirrer with tachometer for mixing, a fixed temperature circulator in order to keep the reaction temperature constant were used in the experiments carried out under atmospheric conditions. Solid material in accordance with the determined solid-liquid ratio was placed in the reactor and $200 \mathrm{~mL} \mathrm{KH} \mathrm{PO}_{4}$ solution was added. After the reactor contents reached the determined temperature the experiment started. The experimental setup is shown in Fig. 2.

Fig. 2: Experimental Setup Used for the Dissolution Process

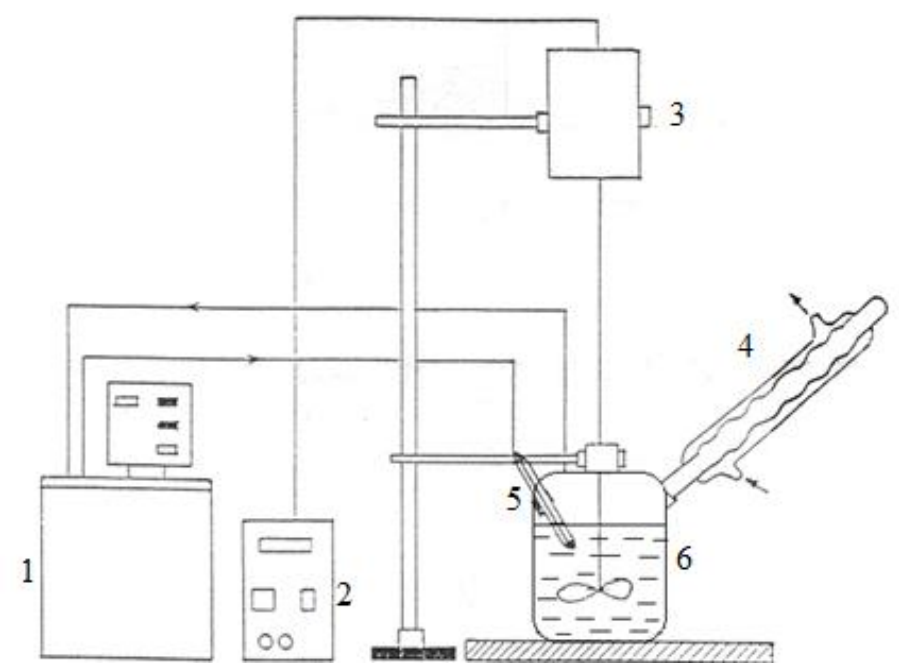

1- Fixed temperature circulator, 2-Speed control tachometer , 3- Mechanical stirrer, 4- Reflux condenser, 5- Thermometer, 6- Jacketted glass reactor

\subsection{Statistical Method}

The optimization of dissolution conditions of the ores has a great importance in the industrial fields. For this reason a lot of studies have been made by researchers using various methods such as Taguchi[12, 14, 15] the factorial experimental design $[8,16-18]$ and the orthogonal central composite design $[19,20]$.

In this study, the Taguchi method was used as the optimization method. Keeping experimental costs to a minimum, the advantage of the Taguchi method over other classic experimental design methods is that as the performance value is brought to the mean target,variability around the target is minimized and the optimum conditions obtained in the laboratory environment can be obtained in the true production environment [21].

During Taguchi method, the following stages were completed [22, 23].

- Determination of performance characteristic and choice of process parameters

- Determination of parameter levels for the process and possible internal interaction between parameters

- Choice of appropriate orthogonal pattern and insertion of parameters

- Completion of experiments in the orthogonal pattern

- Calculation of performance characteristic

- Analysis of experimental results using ANOVA and performance characteristic

- Determination of optimum levels of process parameters

- Confirmation of optimum conditions with confirmation experiments

During identification of optimum levels of parameters, the performance statistical formula for the three characteristics above are:

For situations where larger is better:

$$
\mathrm{SN}_{\mathrm{L}}=-10 \log \left[\frac{1}{\mathrm{n}} \sum_{\mathrm{i}=1}^{\mathrm{n}} \frac{1}{\mathrm{Y}_{1}^{2}}\right]
$$


For situations where smaller is better:

$$
\mathrm{SN}_{\mathrm{S}}=-10 \log \left[\frac{1}{\mathrm{n}} \sum_{\mathrm{i}=1}^{\mathrm{n}} Y_{i}^{2}\right]
$$

For better target value:

$$
\mathrm{SN}_{\mathrm{S}}=-10 \log \left[\sum_{\mathrm{i}=1}^{\mathrm{n}} \mathrm{Y}_{\mathrm{i}}^{2} / \mathrm{S}^{2}\right]
$$

If the aim of the process is to reach maximum value, the parameter levels making the $\mathrm{SN}_{\mathrm{L}}$ value maximum are optimum. If the aim is to reach a minimum, in this situation the parameter levels making $\mathrm{SN}_{\mathrm{S}}$ maximum are optimum.

If the experiment with optimum study conditions in the Taguchi method is not in the experimental plan, in addition to performance value, (Eq.(4))may be used as an additional model to estimate the dissolution percentage.

$\mathrm{Y}_{\mathrm{i}}=\mu+\mathrm{X}_{\mathrm{i}}+\mathrm{e}_{\mathrm{i}}$

As the $Y_{i}$ calculated from experimental results is a point estimate, to determine whether the additional model is sufficient, a confidence interval for estimate error should be created. The confidence interval is found using the equation below [24].

$S_{e}= \pm 2 \sqrt{\left[\frac{1}{n_{0}}\right] * \sigma_{e}^{2} *\left[\frac{1}{n_{r}}\right] \sigma_{e}^{2}}$

$\sigma_{e}^{2}=\frac{\text { sum of sequares due to error }}{\text { degrees of freedom for error }}$

$$
\frac{1}{n_{o}}=\frac{1}{n}+\left[\frac{1}{n_{A i}}-\frac{1}{n}\right]+\left[\frac{1}{n_{B i}}-\frac{1}{n}\right]+\left[\frac{1}{n_{C i}}-\frac{1}{n}\right]
$$

If the estimate error is outside these limits, the additional model may not be sufficient. If the opposite is true, the additional model is sufficient. If the experimental results are given as percentage, before using the $Y_{i}$ equation, omega transformation of obtained percentage values is performed [23]. Later the omega value estimated for optimum conditions from obtained values is found using this equation:

$$
\Omega(\mathrm{db})=-10 \log \left(\frac{1}{\mathrm{P}}-1\right)
$$

After calculations, the same equation is used for inverse transformation.

In this study parameter levels were determined in light of preliminary experiments and inserted into an orthogonal experimental design. To determine uncontrolled effects on the process (noise sources), experiments were repeated twice at separate times under the same conditions and larger, better performance characteristics were chosen as optimization criteria (Eq.(1)).

As the value calculated from (Eq.(4)) is a point estimate, to understand whether the additive model is sufficient or not, the confidence interval for the estimate error was calculated using (Eq.(5)). 


\section{RESULTS AND DISCUSSION}

\subsection{Dissolution Reactions}

The reaction taking place in the solution can be written as follows [25]:

$$
\begin{aligned}
& 4 \mathrm{KH}_{2} \mathrm{PO}_{4} \text { (aq) } \longrightarrow 4 \mathrm{~K}_{(\mathrm{aq})}^{+}+4 \mathrm{H}_{2} \mathrm{PO}_{4}^{-1} \text { (aq) } \\
& 4 \mathrm{H}_{2} \mathrm{PO}_{4}^{-1} \text { (aq) }+4 \mathrm{H}_{2} \mathrm{O}_{(\mathrm{aq})} \longrightarrow 4 \mathrm{H}_{3} \mathrm{O}_{\text {(aq) }}^{+}+4 \mathrm{HPO}_{4}^{-2} \text { (aq) } \\
& 4 \mathrm{~K}_{(\mathrm{aq})}^{+}+2 \mathrm{HPO}_{4}^{-2}{ }_{\text {(aq) }} \longrightarrow 2 \mathrm{~K}_{2} \mathrm{HPO}_{4(\mathrm{aq})}
\end{aligned}
$$

When colemanite ore is added to the $\mathrm{KH}_{2} \mathrm{PO}_{4}$ solutions, the reaction taking place in the solution can be written as follows:

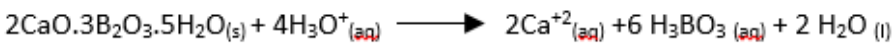

$$
\begin{aligned}
& 2 \mathrm{Ca}_{(\text {(aq) }}^{+2}+2 \mathrm{HPO}_{4}^{-2} \text { (aq) } \longrightarrow 2\left[\mathrm{CaHPO}_{4} \cdot 2 \mathrm{H}_{2} \mathrm{O}\right]_{(\mathrm{s})}
\end{aligned}
$$

The total reaction is as follows:

$2 \mathrm{CaO} .3 \mathrm{~B}_{2} \mathrm{O}_{3} \cdot 5 \mathrm{H}_{2} \mathrm{O}_{(\mathrm{s})}+2 \mathrm{KH}_{2} \mathrm{PO}_{4}(\mathrm{aq})+6 \mathrm{H}_{2} \mathrm{O}_{(\mathrm{aq})} \longrightarrow 2\left[\mathrm{CaHPO}_{4} \cdot 2 \mathrm{H}_{2} \mathrm{O}\right]_{(\mathrm{s})}+4 \mathrm{H}_{3} \mathrm{BO}_{3(\mathrm{aq})}+2 \mathrm{~K}_{2} \mathrm{HPO}_{4(\mathrm{aq})}$

\subsection{Optimization Experiment Results}

The number of parameters determined in optimization studies was 5 , and for each parameter 4 different levels were investigated. The chosen parameter values and levels for the experiments are given in Table 3. In accordance with this situation, an $\mathrm{L}_{16}\left(4^{5}\right)$ factorial fractional experimental design plan was chosen. According to this experimental plan, the heterogeneous mixture obtained at the end of experiments was filtered with a vacuum pump. The filtrate was analyzed for $\mathrm{B}_{2} \mathrm{O}_{3}$ and the results of $\% \mathrm{~B}_{2} \mathrm{O}_{3}$ amounts in filtrate are given in Table 4.

\begin{tabular}{|c|c|c|c|c|c|c|c|}
\hline \multirow{2}{*}{$\begin{array}{l}\text { Experiment } \\
\text { No }\end{array}$} & \multicolumn{5}{|c|}{ Parameter Levels } & \multirow{2}{*}{$\begin{array}{l}\text { 1st Series } \\
\text { Experiments } \\
\mathrm{B}_{2} \mathrm{O}_{3}(\%)\end{array}$} & \multirow{2}{*}{$\begin{array}{l}\text { 2nd Series } \\
\text { Experiments } \\
\mathrm{B}_{2} \mathrm{O}_{3}(\%)\end{array}$} \\
\hline & A & B & C & D & $E$ & & \\
\hline 1 & 1 & 1 & 1 & 1 & 1 & 15.83 & 22,17 \\
\hline 2 & 1 & 2 & 2 & 2 & 2 & 31.95 & 32.61 \\
\hline 3 & 1 & 3 & 3 & 3 & 3 & 35.33 & 38.48 \\
\hline 4 & 1 & 4 & 4 & 4 & 4 & 54,45 & 55.60 \\
\hline 5 & 2 & 1 & 2 & 3 & 4 & 50.14 & 49.32 \\
\hline 6 & 2 & 2 & 1 & 4 & 3 & 90.87 & 87.20 \\
\hline 7 & 2 & 3 & 4 & 1 & 2 & 22.03 & 21.03 \\
\hline 8 & 2 & 4 & 3 & 2 & 1 & 51.76 & 49.32 \\
\hline 9 & 3 & 1 & 3 & 4 & 2 & 48.81 & 44.06 \\
\hline
\end{tabular}

Table3: Parameters and Their Ranges

\begin{tabular}{ll}
\hline Parameters & Values \\
\hline A: Reaction Temperature, $\mathrm{K}$ & $303,313,323,333$ \\
B: Particle size, $\mu \mathrm{m}$ & $1550,780,390,165$ \\
C: Solid/liquid ratio, $\mathrm{g} \mathrm{mL}^{-1}$ & $0.02,0.04,0.08,0.17$ \\
$\mathrm{D}: \mathrm{KH}_{2} \mathrm{PO}_{4}$ concentration, $\mathrm{M}_{\mathrm{E}} \mathrm{Time}, \mathrm{min}$ & $0.50,1.00,1.50,2.00$ \\
\hline
\end{tabular}

\section{Table 4: $\mathrm{L}_{16}\left(4^{5}\right)$ Experimental Plan and Results of Experiments}




\begin{tabular}{llllllll}
\hline 10 & 3 & 2 & 4 & 3 & 1 & 28.40 & 28.63 \\
11 & 3 & 3 & 1 & 2 & 4 & 99.8 & 99.90 \\
12 & 3 & 4 & 2 & 1 & 3 & 67.00 & 60.83 \\
13 & 4 & 1 & 4 & 2 & 3 & 28.15 & 30.42 \\
14 & 4 & 2 & 3 & 1 & 4 & 39.93 & 41.93 \\
15 & 4 & 3 & 2 & 4 & 1 & 99.85 & 99.95 \\
16 & 4 & 4 & 1 & 3 & 2 & 93.96 & 98.65 \\
\hline
\end{tabular}

\subsection{Statistical Analysis}

The data were analyzed using a statistical program. For effective parameters on the solution process and to find their confidence levels, variance analysis (ANOVA) was completed. ANOVA is used to understand whether process parameters are statistically significant or not. To determine the process parameters with most significant effect on the solution process the $F$ test was used. For each parameter of the process, the $F$ value is the ratio of the total square of the deviation error to the total square of the error. Generally parameters with larger $F$ value have greater effect on the process.

The ANOVA analysis results for $\mathrm{B}_{2} \mathrm{O}_{3}$ are given in Table 5. When Table $\mathbf{5}$ is investigated, the highest $F$ values were observed to be for solid/liquid ratio and $\mathrm{KH}_{2} \mathrm{PO}_{4}$ concentration.

Table 5: ANOVA Table for $\mathrm{B}_{2} \mathrm{O}_{3}$ in Optimization Experiment

\begin{tabular}{lllll}
\hline Parameter & SS & Df & MS & F \\
\hline A & 4188.7 & 3 & 1396.2 & 271.07 \\
B & 5004.4 & 3 & 1668.1 & 323.86 \\
C & 5511.9 & 3 & 2837.3 & 550.85 \\
D & 5276.9 & 3 & 1759.0 & 341.49 \\
E & 790.1 & 3 & 263.4 & 51.13 \\
Error & 82.4 & 16 & 5.2 & \\
Total & 23854.4 & 31 & & \\
\hline
\end{tabular}

To obtain optimal dissolution performance, for situations where larger is better performance characteristic (Eq.(1)) has been taken for dissolution of $\mathrm{B}_{2} \mathrm{O}_{3}$. The order of graph in Fig $\mathbf{3}$ is according to the degrees of he influences of parameters on the performance characteristics. The effect of each parameter on the optimization criteria for $\mathrm{B}_{2} \mathrm{O}_{3}$ is shown in Fig. 3 .

Fig. 3: The effect of each parameter on the optimization criteria for $\mathrm{B}_{2} \mathrm{O}_{3}$

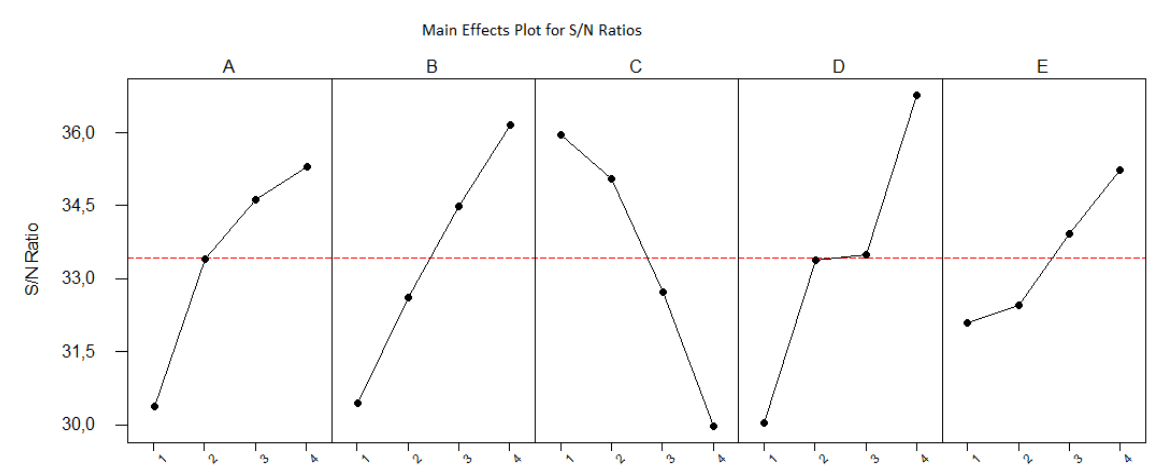


The optimal level of process parameter is the level with the highest SN ratio value calculated by Eq.(1). The numerical value of a maximum point corresponds to the best value for that parameter in Fig. 3. These values are seem to be $\mathrm{A} 4$ (333 K), $\mathrm{B} 4(165 \mu \mathrm{m}), \mathrm{C} 1\left(0.02 \mathrm{~g} \mathrm{~mL}^{1}\right), \mathrm{D} 4(2 \mathrm{M}), \mathrm{E} 4(60 \mathrm{~min})$.

$\mathrm{X}$-ray diffractogram of the solid product obtained from the optimum condition is shown in Fig. 4. As seen from the diffractogram of the solid product in Fig. 4, the basic component is Calcium Hydrogen Phosphate Hydrate $-\mathrm{CaHPO}_{4} 2 . \mathrm{H}_{2} \mathrm{O}$.

Fig. 4: X-ray Diffraction of Solid Product

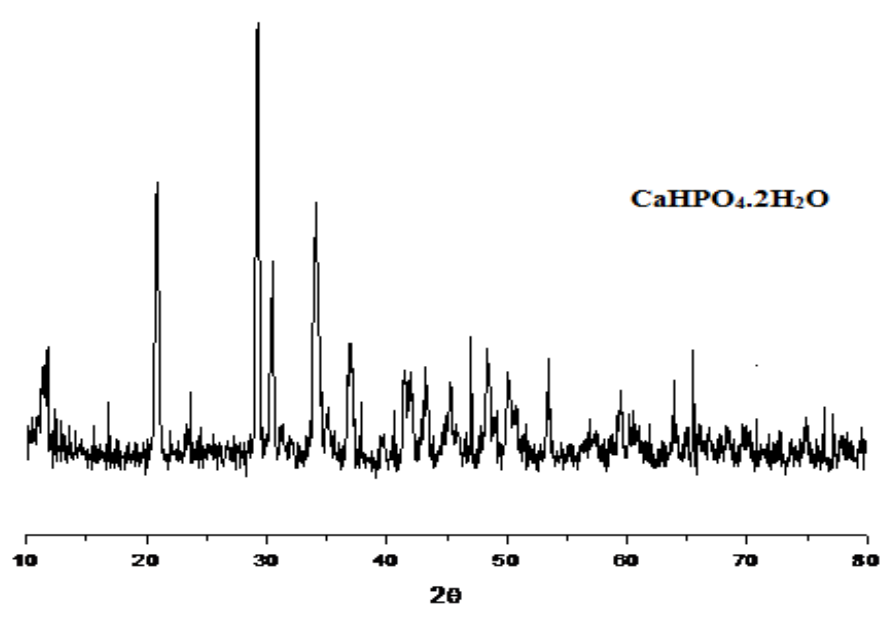

\section{CONCLUSION}

- The effective parameters on the dissolution of colemanite ore in $\mathrm{KH} 2 \mathrm{PO} 4$ solutions are solid/liquid ratio and $\mathrm{KH}_{2} \mathrm{PO}_{4}$ concentration

- The optimum conditions for the maximum $\mathrm{B}_{2} \mathrm{O}_{3}$ dissolution was determined as follows: temperature, $333 \mathrm{~K}$; particle size, $165 \mu \mathrm{m}$; time, $60 \mathrm{~min}$; solid-liquid ratio, $0.02 \mathrm{~g} / \mathrm{mL}$ and $\mathrm{KH}_{2} \mathrm{PO}_{4}$ concentration, $2 \mathrm{M}$.

- Under these optimum conditions $98 \% \mathrm{~B}_{2} \mathrm{O}_{3}$ dissolved.

- As seen from the diffractogram of the solid product in Fig. 4, the basic component is Calcium Hydrogen Phosphate Hydrate $-\mathrm{CaHPO}_{4} 2 . \mathrm{H}_{2} \mathrm{O}$.

- As a result, the additive model is appropriate to describe the dependence of the process on the studied parameters.

\section{Nomenclature}

$\begin{array}{ll}\mathrm{N} & \text { Repetitive experiment number } \\ \mathrm{Y}_{\mathrm{i}} & \text { Performance value } \\ \mathrm{SN}_{\mathrm{L}}, \mathrm{SN}_{\mathrm{S}}, \mathrm{SN}_{\mathrm{TK}} & \text { Performance statistics } \\ \mathrm{Y}_{\mathrm{i}} & \text { Estimated performance value of experiment } \\ \mu & \text { Total average of performance value } \\ \mathrm{X}_{\mathrm{i}} & \text { Total efficiency size of parameter levels used in the } \\ & \text { experiment } \\ \mathrm{e}_{\mathrm{i}} & \text { experimental error } \\ \mathrm{S}_{\mathrm{e}} & \text { confidence interval for effects of parameters } \\ \mathrm{n}_{\mathrm{A} 1} & \text { experiment number belonging to A parameter } \\ \sigma_{e}^{2} & \text { Variance of error }\end{array}$

\section{REFERENCES}

[1] Tombal TD, Özkan ŞG, Ünver İ, Osmanlıŏlu AE. Bor bileşiklerinin özellikleri, üretimi, kullanımı ve nükleer reaktör teknolojisinde önemi/Properties, production, uses of boron compounds and their importance in nuclear reactor technology. Journal of Boron. 2016;1:8695. 
[2] Gönen M, Nyankson E, Gupta RB. Boric Acid Production from Colemanite Together with ex Situ CO2 Sequestration. Industrial \& Engineering Chemistry Research. 2016;55:5116-24.

[3] Davies T, Colak S, Hooper R. Boric acid production by the calcination and leaching of powdered colemanite. Powder Technology. 1991;65:433-40.

[4] Ata ON, Colak S, Çopur M, Çelik C. Determination of the optimum conditions for boric acid extraction with carbon dioxide gas in aqueous media from colemanite containing arsenic. Industrial \& engineering chemistry research. 2000;39:488-93.

[5] Budak A, Gönen M. Extraction of boric acid from colemanite mineral by supercritical carbon dioxide. The Journal of Supercritical Fluids. 2014;92:183-9.

[6] Kuskay B, Bulutcu A. Design parameters of boric acid production process from colemanite ore in the presence of propionic acid. Chemical Engineering and Processing: Process Intensification. 2011;50:377-83.

[7] Yeşilyurt M. Determination of the optimum conditions for the boric acid extraction from colemanite ore in HNO 3 solutions. Chemical Engineering and Processing: Process Intensification. 2004;43:1189-94.

[8] Durak H, Genel Y, Çalban T, Kuşlu S, Çolak S. Optimization of the Dissolution of Tincal Ore in Phosphoric Acid Solutions at High Temperatures. Chemical Engineering Communications. 2015;202:245-51.

[9] Karagöz Ö, Çopur M, Kocakerim MM. Tinkalden Borik Asit Üretiminin Optimizasyonu. 10 Ulusal Kimya Mühendisliği Kongresi2012. p. 299-300.

[10] Abalı Y, Bayca SU, Edgunlu G. Optimization of pure borax pentahdrate extraction from calcined tincal. Physicochemical Problems of Mineral Processing. 2015.

[11] Tunc M, Celik C, Colak S, Kocakerim M. Determination of optimum conditions for dissolution of ulexite in sulphuric acid solutions. Transactions-Institution of mining and metallurgy Section C Mineral processing \& extractive metallurgy. 1999;108.

[12] Doğan TH, Yartaşı A. Optimization of Dissolution of Ulexite in Phosphate Acid Solutions. Journal of the Chemical Society of Pakistan. 2014;36.

[13] Küçük Ö, Kocakerim MM. Optimization of dissolution of ulexite in water saturated with sulphur dioxide. Chemical Engineering and Processing: Process Intensification. 2005;44:1005-11.

[14] Beşe AV, Borulu N, Çopur M, Çolak S, Ata ON. Optimization of dissolution of metals from Waelz sintering waste (WSW) by hydrochloric acid solutions. Chemical Engineering Journal. 2010;162:718-22.

[15] Yeşilyurt M, Çolak S, Çalban T, Genel Y. Determination of the optimum conditions for the dissolution of colemanite in H3PO4 solutions. Industrial \& engineering chemistry research. 2005;44:3761-5.

[16] Tokkan D, Çalban T, Kuşlu S, Çolak S, Dönmez Bn. Optimization of microwave-assisted removal of lead from anode slime in triethanolamine solutions. Industrial \& Engineering Chemistry Research. 2012;51:3903-9.

[17] Çalban T, Kuşlu S, Çolak S. Precipitation conditions of Chevreul's salt from synthetic aqueous CuSO4 solutions. Chemical Engineering Communications. 2009;196:1018-29.

[18] Yalvac Can M, Yildiz E. Phosphate removal from water by fly ash: Factorial experimental design. Journal of hazardous materials. 2006;135:165-70.

[19] Çavuş Dişli F, Kuşlu S, Çalban T, Çolak S. Optimization of Dissolution of Ulexite Mineral at High Temperature in Aqueous and Borax Pentahydrate Solutions Saturated with Carbon Dioxide. Asian Journal of Chemistry. 2014;26.

[20] Çalban T, Çolak S. Optimization of Pure Copper Powders Production from Leach Solutions Containing Copper. Asian Journal of Chemistry. 2014;26.

[21] Çopur M. An Optimization Study of Dissolution of $\mathrm{Zn}$ and $\mathrm{Cu}$ in $\mathrm{ZnS}$ Concentrate with HNO 3 Solutions. Chemical and biochemical engineering quarterly. 2002;16:191-8.

[22] Nian C, Yang W, Tarng Y. Optimization of turning operations with multiple performance characteristics. Journal of Materials Processing Technology. 1999;95:90-6.

[23] Phadke MS. Quality engineering using robust design: Prentice Hall PTR; 1995.

[24] Roy R. A primer on the Taguchi method, 1990. New York. 1990.

[25] Nemodruk AA, Karalova ZK. Analytical chemistry of boron 5 B 10.811. 1965. 